\title{
Curricular Representation of Science Process Skills in Chemistry
}

\author{
Meharunnisa Karadan ${ }^{1}$, Dr. A. Hameed ${ }^{2}$, \\ ${ }^{1}$ Research Scholar, Department of Education University of Calicut, Kerala, India \\ ${ }^{2}$ Assistant Professor, Department of Education University of Calicut, Kerala, India
}

\begin{abstract}
The National Curriculum Framework (NCF, 2005) and Kerala Curriculum Framework_(KCF, 2007) have laid a lot of stress on inclusion of process skills in the curriculum of science subjects. It is very important to develop student's science process skills which have considerable role in educational settings in order to facilitate students' learning abilities, support their critical thinking skills and make them competent in methods of science. Basic science process skills include observing, classifying, measuring and using numbers, making inferences, predicting, communicating and using the relations of space and time. While the integrated science process skills consist of interpreting data, operational definition, control variables, make hypotheses and experimenting. So in the present study analyses the extend of representation of science process skills in 8th grade and 9th grade Chemistry curricula. This was carried out by document analysis method. Findings of the study proves that, representations of basic level process skills and advanced level skills in curriculum of grades eight and nine are sufficient to promote curricular objectives and it can be inferred that the emphasis in the programs underlined by educators were not disregarded.
\end{abstract}

Key words: Chemistry education, Basic process skills, Integrated process skills, chemistry curricula.

\section{INTRODUCTION}

In this modern age, the life of human beings completely relies upon science and technology. Science provides a network analysis of the world that surrounds us, in addition, it makes an attempt to explain and describe certain aspects of our universe. Presently the main goal of our educational system is to provide and equip students with information acquisition skills instead of directly providing them for facing the troubles and challenges of daily life. For this, learning process is more comprehensive rather than learning based on memorization and it requires application of various skills in new situations. Good science education is true to the child, true to life and true to science.

The aim of science education is "to raise all humans as scientifically literate and help them to understand how scientists discover theories" (Aktamis \& Ergin, 2007). In order to realize these aims in science education, the triangle of teachers, students, and curricula should not be ignored. Among this triad, Curriculum plays a pivotal role. It is without doubt that a well-designed curriculum will enhance the efficiency of teaching and learning in multicultural situation.

Presently in Kerala, constructivist principle is used for the process of curriculum transaction. In constructivism, the success mainly depends upon the nature of teacher, provision for self developmental activities and availability of suitable facilities and conditions. In science, it can be acquired through the acquisition of science process skills which is a core educational outcome stipulated in the Curriculum Framework of the science education. In Kerala, teachers are using the textbook as one of the primary instruments for equity, since for a great majority of school going children, as also for their teachers, it is the only accessible and affordable resource for education.

The Science Process Skills (SPS) are the thinking skills that we use to create knowledge, to reflect on problems and to formulate results (Lind, 1998). It has been reported that the SPS helps learners understand Physical Sciences (Cepni et al 1996; Harlen, 1999). Furthermore, it has been maintained that the basis of learning how to recognize, define and, to some extent, solve individual and social problems is learning how to gain the science process skills (Aktamis \& Ergin, 2007). In this way, individuals can use the SPS for identifying the problems in their daily lives and overcoming them via appropriate hypotheses (Liang, 2002). The educational process is always updated in a way that will enable individuals to catch up with the world, and proves to be a pioneering factor in the process of change. The tendency has shifted to training students in a way that will enable them to access knowledge, to distinguish what knowledge is necessary, and to generate new knowledge on the basis of the knowledge they have accessed (Basbay, 2008). This is only possible through higher-level process kills. (Koray et al., 2006).

American Association for the Advancement of Science (AAAS) classified scientific process skills as Basic Scientific Process Skills and Complementary Scientific Process Skills. The former involves observation, 
classification, data recording, measurement, using space/time relationships, using numbers, inference, and prediction. On the other hand, the latter includes changing and controlling variables, interpreting data, and hypothesizing, operational definitions, using data and formulating models, and experimenting (Padilla et al., 1984).

The revised Kerala curriculum includes the following process skills in science curriculum in the secondary stage by taking the suggestion of NCERT. Also, according to this, process skills are classified as basic and integrated process skills. In this, basic process skills like observation, classification, communication, prediction, inference, using numbers, measuring and using space/time relationship can be acquired from elementary classes up to $7^{\text {th }}$ grade and integrated process skills like interpretation of data, making hypotheses, making operational definition, controlling variables and experimenting can be acquired from secondary stages.

\section{Conceptual Framework}

Science process skills are inseparable from the practice of science and play a key role in both formal and informal learning of science content. Both basic and integrated skills are needed to be scientifically literate. Science process skills are not only important for those pursuing careers in science, but most jobs in this new millennium involve using of these skills. These skills are important parts of the core thinking skills that are valued as outcomes of education. They are also essential in enabling children to develop understanding and the ability to identify and use relevant scientific evidence in solving problems and making decisions. Teachers need to help their students develop their process skills into scientific ones, just as they need to help students develop scientific ideas.

In one study, Donmez and Azizoglu (2010) recommended that the skill objectives should be emphasized in teachers' books and that they should cover the science process skills to be used by teachers when necessary during lecturing. Considering these recommendations and the fact that learning these skills can eliminate the idea that Physical Sciences are based on memorization, it is essential that these skills should be incorporated into the curriculum (Harlen, 1999). Also these skills are learning products that are vital to the educational process. Furthermore, these products are actually methods and techniques by which scientists can have access to and process knowledge (Gagne, 1965). With these methods and techniques, people identify their daily problems and solve them through appropriate hypotheses (Liang, 2002).

In a position paper published by NCERT on science education recommended major six criteria for ideal science curriculum. One among them is that a good curriculum has "process validity". It means that the curriculum engage the learner in acquiring the methods and processes that lead to generation and validation of scientific knowledge, and nurture the natural curiosity and creativity of the child in science. Process validity is an important criterion since it helps the student in 'learning to learn' science. Consistent with the criteria above, the objectives, content, pedagogy and assessment for different stages of the curriculum are summarized below.

\section{At the Primary School Stage}

The objectives at this stage are to nurture the curiosity of the child about the world (natural environment, artifacts and people), to have the child engage in exploratory and hands on activities to acquire the basic cognitive and psychomotor skills through observation, classification, inference, etc

\section{At the Upper Primary School Stage}

In this stage, scientific concepts are to be arrived at mainly from activities and experiments. Science content at this stage is not to be regarded as a diluted version of secondary school science. Group activity, discussions with peers and teachers, surveys, organization of data and their display through exhibitions, etc. in schools and neighbourhood are to be an important component of pedagogy.

\section{At the Secondary School Stage}

The students should be engaged in learning science as a composite discipline, in working with hands and tools to design more advanced technological modules than at the upper primary stage, and in activities and analysis on issues surrounding environment and health. Systematic experimentation as a tool to discover/verify theoretical principles, and working on locally significant projects involving science and technology are to be important parts of the curriculum at this stage.

So science education, even at its best, develops competence but does not encourage inventiveness and creativity. This problem can be solved through the process oriented science teaching and learning. At the secondary school stage, concepts that are beyond direct experience may come to occupy an important place in the science curriculum. Since not all phenomena are directly observable, science also relies on inference and interpretation. Though activity-based teaching has been accepted as a paradigm for science education in Kerala and is also reflected in some measure in the textbooks developed at the national and state levels, it has hardly been translated to actual classroom practice. Looking at the complex scenario of science education in India, there are so many issues stand out unmistakably. Consequently, we must use the textbook as one of the primary instruments for universalization of good science education in the country. Textbooks must help realize the basic 
curricular objectives of different stages, discussed earlier. Because of all these reasons the present study is of major importance.

\section{THE PURPOSE OF THE STUDY}

The purpose of the present study is to reveal the extent to which the Science Process Skills are represented in the Chemistry Curricula for Grades 8 and 9 of Kerala state syllabus.

\section{RESEARCH QUESTIONS}

1. What is the extent to which the science process skills are represented in the Chemistry Curriculum for Grade 8?

2. What is the extent to which the science process skills are represented in the Chemistry Curriculum for Grade 9?

\section{METHODOLOGY}

The Chemistry Curricula for Grades 8 and 9 were analyzed completely through document analysis. It is one of the most significant techniques commonly used in Social Sciences. Document analysis is designed "to identify the existence of certain words or concepts in a text or set of texts" (Buyukozturk et al., 2008). In other words, it is the process by which one collects recordings or documents relevant to the study and analyses them in accordance with a particular system. That is, it involves an analysis of written materials on the target phenomenon or phenomena. (Yildrium \& Simsek, 2005).

Accordingly, the document analysis was used in the present study to analyze the words included in the educational attainments and activities in the units of the Chemistry Curricula for Grades $8^{\text {th }}$ and $9^{\text {th }}$ of Kerala state syllabus as well as sample assessment questions at the end of each unit. As a part of this, the investigator firstly identified the Chemistry units of the science textbooks of the $8^{\text {th }}$ and $9^{\text {th }}$ classes, then analyzed each unit by giving importance to the activities included in the text book for identifying process skills included in them. Lastly, classified these skills in to higher and lower order skills on the bases of educational objectives stated in primary and secondary stage. The whole data is analyzed through percentage analysis in order to determine its extent in the respective textbooks.

In this analysis, valid and reliable question types were used with appropriate modification (Turgut $e t$ al., 1997). These question types and the science process skills represented are presented as Appendix. With reference to the list of questions used as the measurement instrument, an analysis was made of the words included in the educational attainments and activities in the units of the Chemistry Curricula for Grades $8^{\text {th }}$ and $9^{\text {th }}$. In this way, it was possible to determine which word or question represented a particular science process skill in the best way possible.

Sample assessment question included in the Chemistry Curriculum for Grade $8^{\text {th }}$ is presented below. It is followed by an analysis of the question with reference to the question type-science process skill relationship tested by Turgut et al. (1997).

Example:

Unit

: Nature of materials

Science process skill represented : Observation

Question

: By comparing and contrasting the materials in different state of matter and fill up the table given below.

\begin{tabular}{|l|l|l|l|}
\hline & Solid & Liquid & Gas \\
\hline Has fixed volume & & & \\
\hline Has fixed shape & & & \\
\hline
\end{tabular}

\section{Analysis of the Question}

It seems that there is a similarity between the first question type (Appendix) -science process skill relationship tested by Turgut et al. (1997) and the question type-science process skill presented above.

This is supported by the similarity between the question by Turgut $e t$ al. (1997) "In what ways did you compare and contrast the objects?" and the statement included in the text book "By comparing and contrasting the materials in different states of matter and fill up the table wherever needed".

\section{ANALYSIS \& FINDINGS}

As a result of the analysis carried out, how science process skills were reflected in chemistry curricula for grade 8 and $9^{\text {th }}$ of Kerala state syllabus are found out and represented in Table 1 and Table 2 respectively. 
Table 1:Scientific Process Skills (SPS) and their Reflection in The Chemistry Curricula For Grade 8.

\begin{tabular}{|c|c|c|c|c|c|c|}
\hline & & & & $\begin{array}{l}\text { Total } \\
\text { SPS }\end{array}$ & $\begin{array}{c}\text { Percentage } \\
(\%)\end{array}$ & $\begin{array}{c}\text { Mean } \\
\text { Percentage }\end{array}$ \\
\hline \multirow{14}{*}{ 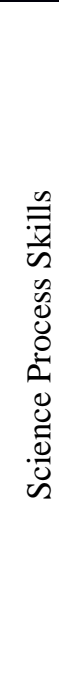 } & \multirow{8}{*}{ 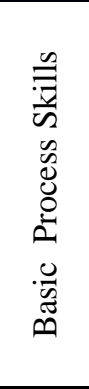 } & 1 & Observation & 11 & 8.73 & \multirow{8}{*}{51.6} \\
\hline & & 2 & Classification & 11 & 8.73 & \\
\hline & & 3 & Communication & 7 & 5.56 & \\
\hline & & 4 & Using numbers & 5 & 3.97 & \\
\hline & & 5 & $\begin{array}{l}\text { Using space/time } \\
\text { relationship }\end{array}$ & 2 & 1.59 & \\
\hline & & 6 & measuring & 5 & 3.97 & \\
\hline & & 7 & prediction & 9 & 7.14 & \\
\hline & & 8 & Inference & 13 & 10.32 & \\
\hline & \multirow{6}{*}{ 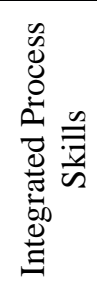 } & 9 & Interpreting data & 15 & 11.90 & \multirow{5}{*}{48.4} \\
\hline & & 10 & Formulating hypotheses & 14 & 11.11 & \\
\hline & & 11 & Controlling variables & 9 & 7.14 & \\
\hline & & 12 & Experimenting & 20 & 15.87 & \\
\hline & & 13 & $\begin{array}{l}\text { Making operational } \\
\text { definitions }\end{array}$ & 5 & 3.97 & \\
\hline & & \multicolumn{2}{|r|}{ Total } & 126 & 100 & 100 \\
\hline
\end{tabular}

From Table 1, it is clear that the basic process skills are represented by $51.6 \%$ in the Chemistry Curriculum for Grade 8 , and higher-level process skills are represented by $48.4 \%$ in the curriculum. Whereas the basic process skills; observation, classification, communication, using numbers, using space/time relationship, measuring, prediction and inference are represented by $8.7 \%, 8.7 \%, 5.5 \%, 3.9 \%, 1.58 \%, 3.9 \%, 7.1 \%$ and $10.3 \%$ respectively and the integrated process skills; interpreting data, formulating hypotheses, controlling variables, experimenting and making operational definitions are represented by $11.9 \%, 11.1 \%, 7.1 \%, 14.2 \%$ and $3.9 \%$ respectively.

Table 2: Scientific Process Skills (SPS) and their reflection in the Chemistry Curricula for Grade 9.

\begin{tabular}{|c|c|c|c|c|c|c|}
\hline & & & & $\begin{array}{l}\text { Total } \\
\text { SPS }\end{array}$ & $\begin{array}{l}\text { Percentage } \\
\quad(\%)\end{array}$ & $\begin{array}{c}\text { Mean } \\
\text { Percentage }\end{array}$ \\
\hline \multirow{13}{*}{ 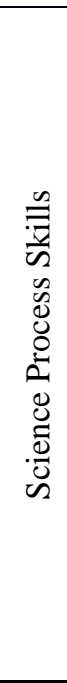 } & \multirow{8}{*}{ 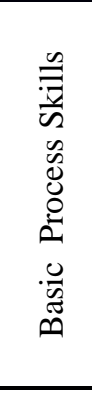 } & 1 & Observation & 24 & 14.46 & \multirow{8}{*}{59} \\
\hline & & 2 & Classification & 11 & 6.63 & \\
\hline & & 3 & Communication & 9 & 5.42 & \\
\hline & & 4 & Using numbers & 4 & 2.41 & \\
\hline & & 5 & $\begin{array}{l}\text { Using space/time } \\
\text { relationship }\end{array}$ & 3 & 1.81 & \\
\hline & & 6 & measuring & 6 & 3.61 & \\
\hline & & 7 & prediction & 13 & 7.83 & \\
\hline & & 8 & Inference & 28 & 16.87 & \\
\hline & \multirow{5}{*}{ 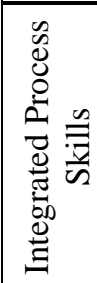 } & 9 & Interpreting data & 22 & 13.25 & \multirow{5}{*}{41} \\
\hline & & 10 & Formulating hypotheses & 5 & 3.01 & \\
\hline & & 11 & Controlling variables & 14 & 8.43 & \\
\hline & & 12 & Experimenting & 21 & 12.65 & \\
\hline & & 13 & $\begin{array}{l}\text { Making operational } \\
\text { definitions }\end{array}$ & 6 & 3.61 & \\
\hline \multicolumn{4}{|c|}{ Total } & 166 & 100 & 100 \\
\hline
\end{tabular}

From Table 2, it is clear that the basic process skills are represented by $59.0 \%$ in the Chemistry Curriculum for Grade $9^{\text {th }}$, and the higher-level process skills are represented by $41 \%$ in the curriculum. Whereas the basic process skills; observation, classification, communication, measurement, using numbers, using space/time relationship, prediction and inference are represented by $13.2 \%, 6.6 \%, 5.4 \%, 2.4 \%, 1.80 \%, 3.6 \%$, $7.8 \%$ and $16.9 \%$ respectively and the integrated process skills ; interpreting data, formulating hypotheses, 
controlling variables, experimenting and making operational definitions are represented by $13.2 \%, 3.0 \%, 8.4 \%$, $12.6 \%$ and $3.6 \%$ respectively.

VI.

CONCLUSIONS AND SUGGESTIONS

A discussion is made on the science process skills in the Chemistry Curriculum for Grades $8^{\text {th }}$ and $9^{\text {th }}$ with reference to Tables 1 and 2, show that the extent to which the basic process skills and integrated process skills are represented, as well as their corresponding percentages in without any order of prominence.

As per the results, the basic process skills are represented by $51.6 \%$ in the Chemistry Curriculum for Grade $8^{\text {th }}$, whereas the integrated process skills are represented by $48.4 \%$ in the curriculum. In addition, the basic process skills are represented by $59.0 \%$ in the Chemistry Curriculum for Grade $9^{\text {th }}$ while the integrated process skills are represented by $41.0 \%$ in the curriculum.

In this curriculum, it is seen that; of the basic skills, inference is the most prominently used_basic process skill, while in integrated process skills; experimenting is the leading skill. These findings indicate that the emphasis laid on laboratory experiments as stated by Berberoglu et al. (2002) has not been ignored in this curriculum. Curriculum should provide opportunities to actively engage in practical activities including manipulation of equipments, observation and systematic recording also.

The study conducted by Trends in International Mathematics and Science Study (TIMSS) in 1999 reported that the science curriculum in Turkey aimed to teach all the topics in the fields of world science, life science, physics, chemistry, environmental science. However, when the data collected from teachers and students were analyzed, it was determined that Turkey was one of the countries where the least number of experiments were carried out in science classes compared to other countries like Australia, England, Israel, Malaysia, The United States of America.

In the curriculum of $9^{\text {th }}$ grade, it is seen that, of the basic skills; inference is the most prominently used basic process skill whereas, interpreting data is the leading skill in the integrated process skills. These findings indicate that the emphasis laid on graphical and other interpretative activities. From the analysis, it is also clear that our curriculum give due consideration to the development of the process domain by developing basic and integrated process skills among the learners. Also the curricular objectives of the process oriented teaching can be effectively conducted by the teachers by inculcating higher level cognitive skills which provide a pathway to make learners as creative scientists. In this way, learners can be enabled to gain the skills that scientists use during their studies. (Lind,1998).

\section{REFERENCES}

[1]. American Association for the Advancement of Science (1993). The Nature of Science. Benchmarks for Science Literacy. New York: Oxford University Press.

[2]. Padilla, M. \& Michael, J. (1990). The Science Process Skills. Research matters - to the science teacher no. 9004. http://www.educ.sfu.ca/narstsite/publications/research/skill.htm.

[3]. Aydın, (2013). Representation of Science Process Skills in the Chemistry Curricula for Grades 10, 11 and 12 / Turkey. International Journal of Education and Practice, 1(5):51-63.

[4]. ATS, 2011. Applications technologiques et scientifiques. Available from http://www.mels.gouv.qc.ca/ sections/programmeformation/secondaire2/medias/6d-pfeq applictech.pdf.

[5]. Aktamis, A. \& Ergin, O.(2008). The effect of scientific process skills education on students' scientific creativity, science attitudes and academic achievements. Asia-Pacific Forum on Science Learning and Teaching, Volume 9, Issue 1, Article 4.

[6]. Harlen, W. (1999). Purposes and Procedures for Assessing Science Process Skills. Assessment in Education, 6(1). 